Acta vet. scand. $1973,14,657-665$.

From the Department of Microbiology and Epizootology, College of Veterinary Medicine, the State Veterinary Medical Institute, Helsinki, and the Institute of Animal Breeding, Agricultural Research Centre, Tikkurila, Finland.

\title{
STIMULATION OF HETEROPHIL HEMAGGLUTININS IN CHICKENS BY A VIRAL VACCINE AND CHICKEN THYROID EXTRACT
}

By

D. Sharma and J. Tuomi

\begin{abstract}
SHARMA, D. and J. TUOMI: Stimulation of heterophil hemagglutinins in chickens by a viral vaccine and chicken thyroid extract. Acta vet. scand. $1973,14,657-665$. - The formation of heteroagglutinins against human group $O$, horse and sheep erythrocytes was studied in groups of chickens injected with various materials. Production of antibodies cross-reacting with some or all of the test cell types was induced both with chicken thyroid extract, with or without adjuvant, and with inactivated infectious bronchitis vaccine with adjuvant. The chicken tissue in the injection materials is considered to be responsible, to a great extent, for the stimulations recorded. Also complete Freund's adjuvant alone, however, had a stimulating effect. The heterogeneity of the antibody response as regards specificity, and differences in the responsiveness of individual chickens, were demonstrated.
\end{abstract}

heteroagglutinins; chicken; immunization; blood grou p.

In connection with studies of experimental allergic thyroiditis chickens were immunized with chicken thyroid extract. A rise of heterophil hemagglutinins (heteroagglutinins) was suspected to have taken place when immunized chicken sera were compared with control chicken sera by the passive hemagglutination method. This induced us to study more systematically the phenomenon of formation of heteroagglutinins.

The natural occurrence of different heteroagglutinins in humans and animals is well known. The rise of heteroagglutinins 
has largely been connected with the stimulatory effect of bacterial flora or bacterial infections (Springer 1970).

Springer \& Schuster (1964) have shown that chicken egggrown viruses possess immunogenic blood group A-like antigens, which in the majority of group A-antigen-deficient humans result in a significant rise of isoagglutinins and isohemolysins. They have also shown that viruses acquire antigenic specificities peculiar to the hast in which they grow.

Viral vaccination of chickens has been reported to cause a rise in other than virus-specific antibodies. Roberts (1970) reported that sera from some chickens vaccinated with viral adjuvant vaccine showed antigammaglobulin activity. Cullen \& Timms (1972) reported that some chickens even when injected merely with aluminium hydroxide developed antigammaglobulin activity. Aho et al. (1966) reported that in swine suffering from Mycoplasma granularum infection there is a rise in warm type antihuman blood group $\mathrm{O}$ agglutinins as well as in gammaglobulin activity.

This paper describes results of experiments wherein groups of chickens were injected with various materials, and the occurrence of agglutinins against human group $O$, horse and sheep erythrocytes was measured.

\section{MATERIAL AND METHODS}

Experimental birds

White Leghorn chickens at 1 and 2 years' age were used. Thirty chickens were divided into 6 groups of 5 birds each. The first 2 groups shown in Tables 1 and 2 were 1-year-old birds, the rest were 2 years old.

\section{Injection material}

Five different injection materials were used:

1. Chicken thyroid extract (CTE). This was prepared and lyophilized as described by Janković \& Mitrovic (1963). Prior to injection the lyophilized extract was reconstituted with distilled water to a concentration of $12 \mathrm{mg} / \mathrm{ml}$.

2. Complete Freund's adjuvant. This adjuvant contained $12 \mathrm{mg} / \mathrm{ml}$ killed Mycobacterium tuberculosis.

3. CTE plus complete Freund's adjuvant. An emulsion was prepared by adding, dropwise, reconstituted CTE to an equal volume of adjuvant under constant mixing with a syringe. 
4. Inactivated Infectious Bronchitis (IB) virus vaccine plus aluminium hydroxide adjuvant. The IB vaccine was from the American Scientific Laboratories, Wisconsin, and contained both Mass. and Conn. types of viruses of chicken embryo origin. The reconstituted live virus vaccine was inactivated at $56^{\circ} \mathrm{C}$ for $30 \mathrm{~min}$. Emulsification of equal volumes of these ingredients was performed as described for injection material no. 3.

5. Aluminium hydroxide adjuvant.

\section{Injection procedure}

Injection materials 1,2 and 3 , in doses of $0.5,0.5$ and $1.0 \mathrm{ml}$, respectively, were each injected into 5 birds. The injections were made subcutaneously into the web of the foot. Materials 4 and 5, in doses of $2.0 \mathrm{ml}$ and $1.0 \mathrm{ml}$, respectively, were each injected i.m. into 5 chickens. In all 5 groups the injections were repeated with the same dose after 21 days, now i.m. in every case. One group consisting of 5 chickens (untreated) served as a control group.

\section{Collection of sera}

In the 5 injected groups bleedings from the wing vein were taken shortly before the injections and twice at weekly intervals after both injections. The control birds were bled according to the same time schedule. The sera were preserved at $-20^{\circ} \mathrm{C}$.

Determination of agglutinin titre against human group $O$, horse and sheep cells

The agglutinin titres were determined by a micro-hemagglutination method using plastic V-shaped-bottom trays (Cooks Engineering Company, Alexandria, Virginia, USA). The sera were inactivated at $56^{\circ} \mathrm{C}$ for $30 \mathrm{~min}$. before the test. Double fold serial dilutions of serum in $0.9 \%$ saline were prepared, starting from serum dilution 1:4. To the second serum dilutions equal volumes of a $0.5 \%$ suspension of washed cells (human group $\mathrm{O}$, Rh positive, or horse or sheep cells) in $0.9 \%$ saline were added. All sera from each group were studied simultaneously. The results were read after keeping the plastic tray at room temperature for $2 \mathrm{hrs}$. The titres were expressed as reciprocals of serum dilutions.

\section{Determination of antigammaglobulin activity}

Bovine gammaglobulin Cohn fraction II (Koch-Light Laboratories, Colnbrook, Bucks., England) was used. The activity against this fraction was determined by a latex fixation test as described by Gell \& Coombs (1968).

The development of antigammaglobulin activity was studied only in groups injected with materials nos. 4 and 5. 


\section{RESULTS}

The agglutinin titres against human blood group $O$ cells in the different groups of chicken are stated in Table 1. Table 2 gives the agglutinin titres against horse and sheep erythrocytes,

T a b l e 1. Occurrence of agglutinins against human blood group 0 cells in chickens injected with different materials.

\begin{tabular}{|c|c|c|c|c|c|c|}
\hline \multirow[t]{3}{*}{ Injection material } & \multirow{3}{*}{$\begin{array}{l}\text { Chicken } \\
\text { no. }\end{array}$} & \multicolumn{5}{|c|}{ Agglutinins } \\
\hline & & \multirow{2}{*}{$\begin{array}{l}\text { before } \\
\text { injec- } \\
\text { tion }\end{array}$} & \multicolumn{2}{|c|}{$\begin{array}{l}\text { after first } \\
\text { injection }\end{array}$} & \multicolumn{2}{|c|}{$\begin{array}{l}\text { after second } \\
\text { injection }\end{array}$} \\
\hline & & & 1 week & 2 weeks & 1 week & 2 weeks \\
\hline \multirow[t]{5}{*}{ thyroid extract alone } & 1 & $<4$ & 4 & 8 & 4 & 16 \\
\hline & 2 & 4 & 4 & 4 & 4 & 4 \\
\hline & 3 & $<4$ & 32 & 32 & 16 & 64 \\
\hline & 4 & 4 & 4 & 4 & 16 & 16 \\
\hline & 5 & 4 & 32 & 32 & 32 & 32 \\
\hline \multirow{5}{*}{$\begin{array}{l}\text { complete Freund's adju- } \\
\text { vant alone }\end{array}$} & 1 & 4 & $<4$ & 4 & $<4$ & 4 \\
\hline & 2 & $<4$ & $<4$ & $<4$ & $<4$ & $<4$ \\
\hline & 3 & $<4$ & 4 & $<4$ & $<4$ & $<4$ \\
\hline & 4 & $<4$ & $<4$ & 16 & 8 & 16 \\
\hline & 5 & $<4$ & $<4$ & $<4$ & $<4$ & $<4$ \\
\hline \multirow{5}{*}{$\begin{array}{l}\text { thyroid extract plus com- } \\
\text { plete Freund's adjuvant }\end{array}$} & 1 & $<4$ & 4 & $<4$ & nd & nd \\
\hline & 2 & $<4$ & 16 & 64 & 32 & 32 \\
\hline & 3 & 4 & $<4$ & 8 & 4 & 16 \\
\hline & 4 & $<4$ & 4 & 8 & 16 & nd \\
\hline & 5 & $<4$ & $<4$ & 16 & 32 & 32 \\
\hline \multirow{5}{*}{$\begin{array}{l}\text { inactivated IB vaccine plus } \\
\text { aluminium hydroxide adju- } \\
\text { vant }\end{array}$} & 1 & $<4$ & $<4$ & $<4$ & $<4$ & $<4$ \\
\hline & 2 & $<4$ & 4 & $<4$ & 32 & 32 \\
\hline & 3 & 4 & 8 & 8 & 8 & 16 \\
\hline & 4 & $<4$ & $<4$ & 4 & 4 & 4 \\
\hline & 5 & 4 & $<4$ & 4 & 8 & 16 \\
\hline \multirow{5}{*}{$\begin{array}{l}\text { aluminium hydroxide adju- } \\
\text { vant alone }\end{array}$} & 1 & 4 & $<4$ & 4 & 4 & 8 \\
\hline & 2 & $<4$ & 4 & 4 & $<4$ & $<4$ \\
\hline & 3 & $<4$ & $<4$ & $<4$ & $<4$ & $<4$ \\
\hline & 4 & 4 & 4 & 4 & 4 & 4 \\
\hline & 5 & $<4$ & $<4$ & nd & $<4$ & 16 \\
\hline \multirow[t]{5}{*}{ control group * } & 1 & $<4$ & $<4$ & $<4$ & $<4$ & 4 \\
\hline & 2 & 4 & $<4$ & $<4$ & 4 & $<4$ \\
\hline & 3 & $<4$ & $<4$ & $<4$ & 8 & 8 \\
\hline & 4 & $<4$ & $<4$ & $<4$ & $<4$ & 4 \\
\hline & 5 & 4 & $<4$ & 4 & $<4$ & 4 \\
\hline
\end{tabular}

bleedings according to the same time schedule as in treated birds.

nd $=$ not done. 
T a b l e 2. Occurrence of agglutinins against horse and sheep erythrocytes in chickens infected with various different materials.

\begin{tabular}{|c|c|c|c|c|c|c|c|}
\hline \multirow[t]{2}{*}{ Injection material } & \multirow[t]{2}{*}{$\begin{array}{c}\text { Chicken } \\
\text { no. }\end{array}$} & \multicolumn{3}{|c|}{$\begin{array}{l}\text { Anti-horse } \\
\text { cell agglutinins }\end{array}$} & \multicolumn{3}{|c|}{$\begin{array}{c}\text { Anti-sheep } \\
\text { cell agglutinins }\end{array}$} \\
\hline & & $\begin{array}{l}\text { before } \\
\text { injection }\end{array}$ & $\begin{array}{l}\text { after first* } \\
\text { injection }\end{array}$ & $\begin{array}{c}\text { after } \\
\text { second } \\
\text { injection }\end{array}$ & $\begin{array}{l}\text { before } \\
\text { injection }\end{array}$ & $\begin{array}{l}\text { after first } \\
\text { injection }\end{array}$ & $\begin{array}{l}\text { after } \\
\text { second } \\
\text { injection }\end{array}$ \\
\hline thyroid extract alone & $\begin{array}{l}1 \\
2 \\
3 \\
4 \\
5\end{array}$ & $\begin{array}{r}<4 \\
8 \\
<4 \\
<4 \\
128\end{array}$ & $\begin{array}{r}4 \\
8 \\
16 \\
8 \\
256\end{array}$ & $\begin{array}{r}8 \\
32 \\
64 \\
8 \\
256\end{array}$ & $\begin{array}{r}<4 \\
<4 \\
<4 \\
<4 \\
8\end{array}$ & $\begin{array}{r}4 \\
<4 \\
4 \\
<4 \\
16\end{array}$ & $\begin{array}{r}8 \\
<4 \\
4 \\
<4 \\
16\end{array}$ \\
\hline $\begin{array}{l}\text { complete Freund's ad- } \\
\text { juvant }\end{array}$ & $\begin{array}{l}1 \\
2 \\
3 \\
4 \\
5\end{array}$ & $\begin{array}{r}<4 \\
<4 \\
4 \\
<4 \\
4\end{array}$ & $\begin{array}{r}4 \\
4 \\
16 \\
32 \\
4\end{array}$ & $\begin{array}{r}<4 \\
16 \\
32 \\
64 \\
4\end{array}$ & $\begin{array}{r}4 \\
<4 \\
<4 \\
<4 \\
<4\end{array}$ & $\begin{array}{l}<4 \\
<4 \\
<4 \\
<4 \\
<4\end{array}$ & $\begin{array}{r}4 \\
8 \\
16 \\
8 \\
4\end{array}$ \\
\hline $\begin{array}{l}\text { thyroid extract plus } \\
\text { complete Freund's ad- } \\
\text { juvant }\end{array}$ & $\begin{array}{l}1 \\
2 \\
3 \\
4 \\
5\end{array}$ & $\begin{array}{l}<4 \\
<4 \\
<4 \\
<4 \\
<4\end{array}$ & $\begin{array}{r}<4 \\
<4 \\
<4 \\
32 \\
4\end{array}$ & $\begin{array}{r}\text { nd } \\
<4 \\
<4 \\
<4 \\
16\end{array}$ & $\begin{array}{r}4 \\
<4 \\
<4 \\
<4 \\
<4\end{array}$ & $\begin{array}{r}8 \\
8 \\
4 \\
<4 \\
<4\end{array}$ & $\begin{array}{r}\text { nd } \\
4 \\
4 \\
<4 \\
<4\end{array}$ \\
\hline $\begin{array}{l}\text { inactivated IB vaccine } \\
\text { plus aluminium hydroxide } \\
\text { adjuvant }\end{array}$ & $\begin{array}{l}1 \\
2 \\
3 \\
4 \\
5\end{array}$ & $\begin{array}{r}4 \\
<4 \\
<4 \\
<4 \\
4\end{array}$ & $\begin{array}{r}64 \\
8 \\
64 \\
32 \\
8\end{array}$ & $\begin{array}{r}64 \\
128 \\
64 \\
32 \\
8\end{array}$ & $\begin{array}{r}<4 \\
<4 \\
<4 \\
<4 \\
8\end{array}$ & $\begin{array}{r}16 \\
<4 \\
16 \\
32 \\
16\end{array}$ & $\begin{array}{l}16 \\
16 \\
16 \\
16 \\
16\end{array}$ \\
\hline $\begin{array}{l}\text { aluminium hydroxide } \\
\text { adjuvant alone }\end{array}$ & $\begin{array}{l}1 \\
2 \\
3 \\
4 \\
5\end{array}$ & $\begin{array}{r}4 \\
4 \\
<4 \\
16 \\
16\end{array}$ & $\begin{array}{r}8 \\
8 \\
4 \\
16 \\
16\end{array}$ & $\begin{array}{r}8 \\
<4 \\
4 \\
32 \\
8\end{array}$ & $\begin{array}{l}<4 \\
<4 \\
<4 \\
<4 \\
<4\end{array}$ & $\begin{array}{l}<4 \\
<4 \\
<4 \\
<4 \\
<4\end{array}$ & $\begin{array}{l}<4 \\
<4 \\
<4 \\
<4 \\
<4\end{array}$ \\
\hline control group * & $\begin{array}{l}1 \\
2 \\
3 \\
4 \\
5\end{array}$ & $\begin{array}{r}<4 \\
4 \\
<4 \\
8 \\
4\end{array}$ & $\begin{array}{r}<4 \\
<4 \\
<4 \\
4 \\
4\end{array}$ & $\begin{array}{r}<4 \\
4 \\
8 \\
4 \\
4\end{array}$ & $\begin{array}{r}<4 \\
<4 \\
<4 \\
8 \\
<4\end{array}$ & $\begin{array}{r}<4 \\
<4 \\
<4 \\
4 \\
4\end{array}$ & $\begin{array}{r}<4 \\
<4 \\
4 \\
8 \\
<4\end{array}$ \\
\hline
\end{tabular}

* the higher titres from 2 measurements after each injection given.

* bleedings according to the same time schedule as in the treated birds. $\mathrm{nd}=$ not done on account of death of the bird. 
measured for comparative purposes. Table 3 shows the results of measurements of anti-bovine gammaglobulin activity in 2 chicken groups. Table 2 gives the results in a more concentrated form than Table 1: only the highest titres measured after each injection were entered. Similar slight fluctuations in titres as can be seen in Table 1 also occur, but the complete results presented in Table 1 are thought to suffice to illustrate the phenomenon of fluctuation.

Definite rises measured against human group $O$ cells took place in the groups injected with chicken thyroid extract, either without or with adjuvant, and in the group injected with the inactivated IB vaccine with adjuvant. There was, however, a distinct variation of response among the individual birds: in some of them no rise in agglutinins was recorded.

In the groups injected with adjuvants alone, 1 bird of each group demonstrated a slight but definite rise of anti-human group $O$ agglutinins. Even in the untreated control group 1 of the chickens reacted similarly.

The rise of agglutinins against horse and sheep erythrocytes was most definite in the group injected with the inactivated IB vaccine with adjuvant. In the other groups rises of the titres occurred in individual birds, except in the group injected with

Table 3. Occurrence of anti-bovine gammaglobulin activity in chickens injected with IB vaccine or aluminium hydroxide adjuvant.

\begin{tabular}{|c|c|c|c|c|c|c|}
\hline \multirow[t]{3}{*}{ Material injected } & \multirow{3}{*}{$\begin{array}{c}\text { Chicken } \\
\text { no. }\end{array}$} & \multirow{3}{*}{$\underset{\substack{\text { before } \\
\text { injection }}}{ }$} & \multicolumn{4}{|c|}{ Anti-gammaglobulin activity } \\
\hline & & & \multicolumn{2}{|c|}{$\begin{array}{l}\text { after first } \\
\text { injection }\end{array}$} & \multicolumn{2}{|c|}{$\begin{array}{l}\text { after second } \\
\text { injection }\end{array}$} \\
\hline & & & 1 week & 2 weeks & 1 week & 2 weeks \\
\hline \multirow{5}{*}{$\begin{array}{l}\text { IB vaccine plus alumi- } \\
\text { nium hydroxide adjuvant }\end{array}$} & 1 & - & - & - & + & 一 \\
\hline & 2 & - & - & - & + & + \\
\hline & 3 & 一 & - & + & - & + \\
\hline & 4 & 一 & 一 & - & + & + \\
\hline & 5 & 一 & - & - & - & - \\
\hline \multirow{5}{*}{$\begin{array}{l}\text { aluminium hydroxide } \\
\text { adjuvant alone }\end{array}$} & 1 & - & 一 & - & - & - \\
\hline & 2 & - & - & - & - & - \\
\hline & 3 & 一 & - & 一 & - & - \\
\hline & 4 & - & - & - & - & - \\
\hline & 5 & 一 & 一 & nd & + & + \\
\hline
\end{tabular}

nd $=$ not done. 
aluminium hydroxide alone and in the control group, where no definite changes could be recorded.

Four of the chickens injected with the inactivated IB vaccine with adjuvant and 1 of those injected with aluminium hydroxide alone developed anti-bovine gammaglobulin activity during the course of the experiment.

\section{DISCUSSION}

The results from the control group, and some of the pre-injection titres are in agreement with the previous knowledge of the natural occurrence of heteroagglutinins. Whether changes of 1 dilution step in the sequential titres of certain other control chickens also signify a real change or are based on technical scattering is not known.

Both from degree of the rises in titre in individual birds and from the number of birds showing a reaction it can be concluded that immunization with thyroid extract and with the inactivated IB vaccine with adjuvant caused a stimulation of heteroagglutinin formation. It is also strongly suggested by the results that complete Freund's adjuvant alone had a similar, though weaker, effect. As regards the aluminium hydroxide adjuvant when injected alone, any stimulative effect which may have existed remains questionable. It is pointed out that Cullen \& Timms (1972) recorded a response to aluminium hydroxide in formation of a special type of antibodies (see p. 658).

Another general observation is that most of the groups reacting to the injection contained individual birds with no response recorded. The explanation for these individual differences is not known. It may depend on antigenic heterogeneity of the population injected and upon the immunological tolerance of the non-responding individuals.

It is further clearly readable from the results that the responses could differ quantitatively and even qualitatively among individuals as regards the specificity of the antibodies formed. The heterogeneity as well as the antibody responses in general, to types of injection used, and the differences in the quality of responses between individuals are thus made conspicuous.

On the basis of the results of Springer \& Schuster (1964) concerning the isoagglutinin stimulation by influenza vaccine it is presumed that the formation of different hemaglutinins caused 
by vaccination with the inactivated IB vaccine with adjuvant depends, not on the virus-specific substances, but on the chick embryo tissue injected or on the virus envelope which has acquired chicken cell specificities. The similarity of the response induced by the chicken thyroid extract supports the idea of chicken tissue as the active part. Differences in the histocompatibility between individuals of the same species may suffice to explain the occurrence of the successful antigenic stimulations recorded by the indicator system employed, as well as the differences in individual reactivity among chickens.

The above theory does not, of course, apply to the responses demonstrated to follow on treatment with complete Freund's adjuvant alone. Cullen \& Timms have put forward a hypothesis of tissue damage leading to an autoimmune response as the mechanism of the adjuvant effect. Whether Mycobacterium component of the adjuvant used by us might have any cross-reacting epitopes is not known. In general, stimulations by isoantigens and autoantigens are most probably responsible for the responses observed in the present study.

The nature of epitopes on the cell types studied, specific to which cross-reacting antibodies were formed, has not been clarified. To find out whether, for instance, the $\mathrm{O}$ antigen $(\mathrm{H}$ antigen) of the $\mathrm{ABO}$ system was involved in the case of agglutination of human $O$ type cells would have demanded, as the first step, absorption studies with cells of other human blood groups. The agglutinins observed to react against a given cell type used in the present tests may very well, in addition, have consisted of a heterogenous population as regards specificity. Such heterogeneity was demonstrated by $A$ ho et al. (1966) in certain swine sera capable of agglutinating human blood group $O$ cells.

No definite correlation between the occurrence of agglutinins and antigammaglobulin factor was suggested by the results. The formation of antigammaglobulin activity thus appears at present only as an additional indicator of heterogeneity of the responses to the types of injection used.

\section{REFERENCES}

Aho, K., W. P. Switzer, R. W. Lightfoot Jr. \& C. L. Christian: Serological features of Mycoplasma arthritis in swine. J. Immunol. $1966,96,646-649$. 
Cullen, G. A. \& L. M. Timms: Diagnosis of Mycoplasma infection in poultry previously vaccinated with killed adjuvant vaccines. Brit. vet. J. $1972,128,94-99$.

Gell, P. G. H. \& R. R. A. Coombs: Clinical Aspects of Immunology. Blackwell Scientific Publications, Oxford 1968, p. 24.

Janković, B. D. \& K. Mitrović: Experimental allergic thyroiditis in the chicken. Nature (Lond.) 1963, 200, 186-187.

Roberts, $D$. H.: Non-specific agglutination reactions with Mycoplasma gallisepticum antigens. Vet. Rec. 1970, 87, 125-126.

Springer, G. F.: Importance of Human Red Cell Surface Structures in Reactions between Man and Microbes. Blood and Tissue Antigens. ed. David Aminoff, AP Publication 1970, 265-287.

Springer, G. F. \& R. Schuster: Stimulation of isohemolysins and isohemagglutinins by influenza virus preparations. Vox Sang. (Basel) 1964, 9, 589-598.

\section{SAMMANFATTNING}

Stimulation av heteroagglutininer $i$ höns med ett virus vaccin och höns-sköldkörtelextrakt.

Bildandet av heteroagglutininer mot humana grupp O-, häst- och fårerytrocyter undersöktes i grupper av höns, som injicerats med olika material. Produktionen av immunkroppar, som korsreagerade med en eller flere av testcelltyperna, inducerades av både höns-sköldkörtelextrakt, med eller utan adjuvans, och av inaktiverat infektiöst bronkitis vaccin tillsammans med adjuvans. Hönsvävnaden i injektionsmaterialet ansågs till stor del förorsaka de observerade stimulationerna. Emellertid visade också ,,complete Freund's“ adjuvans som sådant en stimulerande effekt. Heterogeniteten av immunkroppssvaret med avseende av specificiteten och skillnader i reaktiviteten hos enskilda höns påvisades.

(Received July 3, 1973).

Reprints may be requested from: Jaakko Tuomi, Department of Microbiology and Epizootology, College of Veterinary Medicine, Hämeentie 57, SF-00550 Helsinki 55, Finland. 